石油技術協会誌 第 80 巻 第 4 号 （平成 27 年 7 月） $249 \sim 259$ 頁 Journal of the Japanese Association for Petroleum Technology

Vol. 80, No. 4 (July, 2015) pp. 249 259

\begin{tabular}{l}
\hline 講 演 \\
Lecture \\
\hline
\end{tabular}

日本のエネルギー政策と水素エネルギーの展望*

内田裕 久 ${ }^{* *+}+$

(Received August 5, 2015 ; accepted September 4, 2015)

\title{
Japan's Energy Policy and Prospects of Hydrogen Energy
}

Hirohisa Uchida

はじめに

今日は初めに，原子力とは何かについてお話します。日 本のエネルギー政策を語る上で，避けて通れないところで す。これに係る問題として地球の温暖化の問題があります。 次に, 再生可能エネルギー, 水素エネルギーついてお話し ます。水素を燃料電池以外にも, 農業, 陸上養殖に利用す る方法もあるので，これもぜひ紹介したいと思います。

\section{東日本大震災と原子力災害}

私は，人間の安全保障，ヒューマンセキュリティーとい う観点から，この 4 年間に海外十数力国で自然災害と原子 力災害について話をしてきました。なぜかというと，日本 がこういうことを全く海外に発信してこなかつたからです。

東京電力福島第一原子力発電所のメルトダウンが起きた 事故では，津波が原因で緊急冷却機能が動作しなかつたと いうことになっていますが，正確な原因はまだによく分か りません。

東海大学の元医学部長で, 国会事故調（東京電力福島原 子力発電所事故調査委員会）の委員長を務められた黒川清 氏（図 1 左）は調査委員会の報告書をまとめましたが，国 会はこの報告書を 1 回も使っていません。「責任の所在も なく，これが先進国のあるべき姿なのか」と黒川先生は嘆 いておられます。

また, JST（科学技術振興機構）の理事長も務めた北澤 宏一氏（図 1 右）は，民間事故調（福島原発事故独立検証 委員会）の委員長を務められました。私とは材料分野の仲 間で，超伝導の分野では大変活躍された科学者でした。昨

* 平成 27 年 6 月 9 日, 平成 27 年度石油技術協会春季特別講演会にて講 演 This special lecture was delivered at the 2015 JAPT annual meeting held in Tokyo, Japan, on June 9, 2015

** 東海大学工学部 School of Engineering, TOKAI University

† Corresponding author : E-Mail : huchida@keyaki.cc.u-tokai.ac.jp
年の今頃はビールを飲みながら,「原子力発電は人間社会 にとってリスクが大きすぎる」と仰っておられましたが, 残念ながらお亡くなりになりました。

未解明のまま原発を再稼働するというのは, 政治が決め ていることです。科学者が決めていることだとは到底思え ません。

2015 年 5 月 14 日にウィーンで発表された IAEA のプレ ス向けリポートで報告されているように，米国の指導で日 本に最初に設置された福島第一原発施設は, その後, 地震 や津波による危険が予見されていたにもかかわらず，東京 電力も国も具体的な対処をしていなかつたと厳しく批判し ています。米国では, ハリケーン対策として重要なシステ ムは地下に確保します。そのやり方をそのまま踏襲してい たために, 津波が来たときに冷却系は水没してしまいま した。

私は日本の原発は安全であると信じていました。私自身, ピッツバーグの東芝ウェスティングハウスエレクトリッ ク・カンパニーに行き, 副社長ともお会いして, 「原子力 人材をアジアで育てたい」とアジアの原子力人材育成教育 に関する協定を締結したのも当時東海大学工学部長だった 私自身です。しかし，それから何年かして福島で予想もし なかった原子力災害が起きました。

\section{社会技術とリスク}

私は, 日本の原発はもう少しまともなシステムだと思つ ていました。私自身も技術屋ですから，あの事故後の状況 や対応できない現状を見ると, 原子力発電を人間社会の技 術として本当に認めていいものかどうか疑問に思います。

原子力の関係者は,「どんな技術にもリスクがある」と 言います。皆さんは, 新幹線に乗るときにシートベルトを しますか。乗り合いバスに乗るときにシートベルトをしま すか。交通事故によるリスクがあるのにシートベルトはし ませんね。なぜでしょうか。長年の安全運行の実績の積夕 
重ねがあるからです。しかし，私たちは，福島であの原子 力災害を経験してしまいました。事故処理にはあと何十年 以上もかかります。これを同じ社会技術のリスクと考えて いいのでしょうか。

私の父親の出身は福井県です。福井県に立ち並ぶ原発で メルトダウンが起きれば, 真冬であれば福井県の日本海側 の住民たちは避難したくても避難できません。道路は雪に 閉ざされて凍り付いて, 車も走れません。人の移動は不可 能なのです。

基本的に人間社会の中で使っていい技術かどうか，厳し く考えないといけません。私は，生前の本田宗一郎さんに お世話になりました。本田さんは,「技術っていうのは人 を幸せにするものであって，不幸せにするもんじゃ駄目な んだ」といつもお話しされていました。私はそれが技術屋 の基本的な姿勢だと確信していますし, 大学では工学部の 学生たちにも話しています。

\section{自分で空間放射線量を測定しよう}

私は昭和 44 年以来, 春, 夏, 秋には杤木県北部の那須 によく行きます。2011年から自分で空間放射線量を測定 しています。 4 年前に比べて今は半分ぐらいに下がってき ていますが, 地面とか少し低地のほうに行くと, まだまだ かなり高い状況です。

「この地域を洗浄する」と那須町から連絡が来たので,「ど うぞ」と申し上げました。しかし, 污染された森林が雨に 濡れて，しずくが地面に落ちて，低地に流れてくれば，洗 浄する意味はありません。福島県だけではなく, 北関東一 帯は相当放射性物質で污染されています。

比較的高価な放射線計測器に比べて, 単三電池 1 本で測 れる, セシウム 137 の放射能測定に特化した簡易型の測定 器を 5 千円ぐらいで購入できます。東海大学の学生はこれ を持って事故を起こしたチェルノブイリ原発まで行き, 測 定してきましたが，デー夕を見ても問題なく使えます。こ ういう簡易型の測定機器を持って, 自分で地域の放射線量 を測ると空間放射線の実感がわくと思います。

東北自動車道に沿つて北上し, 途中の休憩施設で地面の 所を測つてみてください。大体, 杤木県矢板あたりから北 の方に行くに従って計測值が上がっていきます。

\section{原子力とは何か}

「原子力工学」イコール「原発」ではないということを ぜひ知っていただきたいと思います。原子力とは, 原子の 力を利用する技術です。不安定な原子構造から, より安定 した原子構造に変化するときに, 粒子や電磁波のかたちで 出てくるのが「放射線」と言われているものです。大きく 分けて, エックス線, ガンマ線などの電磁放射線と, アル ファ線, ベー夕線, 中性子線などの粒子放射線があります (図 2)。

原子力は発電以外に, 核兵器への応用もありますが, 医 療, 農業, 工業などの産業で非常に役立っています。

例えば，重粒子線を使つたがん治療がありますが，つい
最近, 神奈川県にも導入されました。90歳近い私の母親は, 5 年ほざ前に子宮がん治療後に放射線を使つて再発防止治 療を施されましたが，いまだに再発していません。医療へ の放射線利用はとても重要な技術だと思っています。

もう 1 つ, 意外と忘れているのが宇宙開発です。高度を 上げていくほど, 私たちは太陽や銀河系から来る宇宙放射 線を多量に浴びます。宇宙空間での放射線防御のためのサ イエンスや技術もとても必要です。

水素のような軽い元素は, お互いに一緒になって重くな り, 安定な元素へと安定化しようとします。これが核融合 反応の原理です。ウランのような重い元素は, 中性子を当 てて分解することで, より軽い元素になる傾向があります。 核分裂反応です。いろいろな元素の結合エネルギーを見比 べてみると，宇宙で一番安定な元素が鉄です。

わずかな質量変化が膨大なエネルギーに変換されるとい う核反応はアルベルト・アインシュタインが見つけた知見 ですが，うまく使えば人類のために役に立つ非常に重要な 発見であると私は思っています。

太陽からは常に太陽風や太陽磁場が地球に吹き付けられ ていますが, 幸い, 地球には地球磁場があって, これをか なりガードしています。この地磁気のガードで私たちはこ うやって生きているわけです。太陽から来る特定の粒子は, 今もこの建物や私たちの身体を通過しているのです。

さらに大きい銀河系から見れば, 天の川から大量の宇宙 線が地球系に降り注いでいるのも事実です。これが地球温 暖化の 1 つのメカニズムに関わっているという指摘がある ので, あとでその話をします。まさに宇宙空間は放射線で 満ちており，宇宙開発は放射線との闘いともいえます。

原子力工学科の学生に,「原発で働きたい, 就職したい人」 ときくとほとんどいません。就職先を考えるときには, もつ と広い視野で, 宇宙開発, 医療, 産業あるいは放射線環境 管理などの分野で活躍することも考えようと話していると ころです。

東海大学の湘南校舎では, 私の仲間が 2011 年 3 月の事 故直後から大学に泊まり込んで, キャンパスの放射線測定 をずっとやっていました。私は, 3 月下旬, 平塚市辺りの キャンパスで得られたデータを持って文科省に行きまし た。3 月 18 日ぐらいからヨウ素の痕跡はもうなかつたので, 「こんなデータがありますよ」と言つたら, その時点で, 国にはこういう具体的なデー夕はありませんでした。この 国の危機管理は大丈夫なのかと思いましたが, これが実態 です。

当時のデータは, 東海大学工学部原子力工学科のホーム ページでいまも日本語と英語で公開しています。なぜ英語 かというと, 事故直後, 留学生がみんな帰国しまったので, 留学生諸君に呼びかけるためです。「データを見てくださ い。この地域は大丈夫ですよ。皆さん, 戻ってきてくださ い」という呼びかけでした。

\section{日本のエネルギー政策}

エネルギー政策は, 科学技術ではなくて政治が決めます。 
政治は政治家が決めるなら，その政治家を選ぶのは私たち です。ここは私たちが認識すべき重要なポイントだと思い ます。

1970 年代から, 日本の脆弱なエネルギー供給構造の強 化, クリーンエネルギー・省エネルギー技術開発は必須だ と同じことが繰り返し言われてきています。

電源構成の推移（図 3）をみると, 原油の輸入は減って きて, LNGが増えています。ただし, 電力全体の消費量 は頭打ちです。省エネ効果の結果なのか，あるいは日本の 産業が停滞してきているのか，心配なところもあります。 市場の動きとエネルギーの動きは，常に両方同時に見てい かないといけません。

神奈川県では, 川崎市が京浜臨海工業地帯を中心に水素 エネルギーなどの開発に非常に力を入れています。それに は，大きな理由があります。原油輸入が減り，原油夕ンク 利用率が下がる将来を見据えて，水素を中心とした新しい 産業構造を模索しているからです。

去年出た政府のエネルギー基本計画には具体的な数字が 出ていませんでした。しかし，この 4 月，政府は電源構成 に関してベストミックス案を公開しました。そこには原子

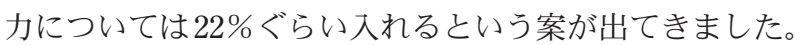
再生可能エネルギーは，もう少し大きくなるかと思ったら 意外と低く，20\%程度でした。30\%には到底いきません。

神奈川県の黒岩祐治知事は, 再生可能エネルギー比率を $35 \%$ にすると主張しています。私は，過去 3 年近く黒岩知 事の参与としてアドバイザーをやってきました。黒岩知事 は，現在も太陽エネルギーを中心にスマートエネルギー政 策を積極的に展開しています。エネルギ一政策は腰を据え て，しっかり方向付けをしないと，ぞこへ行ってしまうか 分かりません。勝手に都合よく，政治的に決められてしま うことになります。

私は水素エネルギーが専門ではありますが，世界に誇る ベき日本のクリーンな石炭火力発電, 天然ガス火力発電を もつと使うべきだと考えています。神奈川県磯子区にある J-POWER（電源開発）の石炭火力の SOx と NOx の排出 量のデー夕を見ると，世界の中でも，あるいは日本の古い タイプの火力発電施設に比べても，圧倒的に排出量が少な い。石炭火力は安くて安定しています。一方，原油価格と 天然ガス価格は高止まりで，変動も大きい（図 4)。

日本の産業力を維持していくうえでも，世界に誇る日本 のクリーン火力技術を駆使してベースロード電源として, 化石燃料をしっかりと使っていくことが大事です。

東京電力の LNG 川崎火力発電所は, もうじきエネルギー 変換効率が $60 \%$ 超えの 2 号系が稼働しだします。世界最 高です。また, 石炭火力でも, IGCC（石炭ガス化複合発電） で $50 \%$ 超になりつつあります。日本の火力発電の技術を 海外でももつと利用すれば, $\mathrm{CO}_{2}$ 排出量も大きく下がりま す。電源開発が出しているデータによれば，世界の $\mathrm{CO}_{2}$ を 15 億卜ン以上減らすことができるといわれています。

\section{$\mathrm{CO}_{2}$ は大事な資源，悪者ではない}

私自身，いつも変だと思うのは，なぜ $\mathrm{CO}_{2}$ は悪者扱い されるのかということです。今, 緑の葉がどんどん成長し ています。これは光合成の結果ですね。 $\mathrm{CO}_{2}$ がなければ植 物は成長しません。皆さん,このことを意外と忘れていて, $\mathrm{CO}_{2}$ が悪者みたいな言い方をします。農作物の成長を促進 するために，ビニールハウスの中に二酸化炭素をまくので す。

たとえばドイツでは, 再生可能エネルギ一由来の余った 水素と $\mathrm{CO}_{2}$ からメタンを造るとか, アウディという自動 車会社は水と二酸化炭素からディーゼル燃料を造っていま す。また，ドイツの BASF やスイスのチューリッヒ工科大 学では, $\mathrm{CO}_{2}$ から化学製品, ファイバー, ジェット燃料に する開発をすでにスタートしています。

$\mathrm{CO}_{2}$ なしに植物も作物は育ちません。今は人工光合成の 研究も進んでいます。

私は, $\mathrm{CO}_{2}$ から付加価值のあるものをいかにして造りだ すか, 石油化学系の会社はもつと積極的にやるべきだと 思っています。 $\mathrm{CO}_{2}$ を使って新商品, 新プロセスをぜひ創 りだしてください。

NEDO でも，去年からソーラー水素など製造プロセス 技術開発と $\mathrm{CO}_{2}$ 資源化プロセス技術開発が始まっていま す。再生可能エネルギーを使いながら, 最終的には水素と 二酸化炭素を使って，いろいろな製品にしていこうという 開発です。まさに最先端のトレンドです。

$\mathrm{CO}_{2}$ が大気中に増え過ぎるのは良くないにしても, $\left\lceil\mathrm{CO}_{2}\right.$ を減らせ」の一本調子ではなく, 少なくとも, これをどう やって使っていくかという, 新技術の開発もぜひお願いし たいと思います。

\section{$\mathrm{CO}_{2}$ は地球温暖化の主因か？}

さて, $\mathrm{CO}_{2}$ は地球温暖化の主因でしょうか。科学的な確 認をしておきたいと思います。

参考になる本があります。私の研究仲間で，長年にわた り水素と材料の研究を行ってきた研究者で, 長く中央大学 理工学部に勤務されていた深井有先生の「気候変動とエネ ルギー問題 $-\mathrm{CO}_{2}$ 温暖化論争を超えて」（深井有著・中央 公論新社）です。これは中公新書から出ています。

今, 小・中・高で教えているのは, 地球の温度が産業革 命の頃から一気に上がっているというデータです。大気中 の $\mathrm{CO}_{2}$ 濃度も, この頃から一気に増えています。通常は この時期だけを強調しています。しかし, 学生のレポート だったら，これはアウトです。「何でそのような短期間だ け見て, 将来を予想できるのか。もつと長いスパンで見ろ」。

もつと過去まで遡れば, 大気中の $\mathrm{CO}_{2}$ 濃度変化とは無 関係に, 地球の温度は高い時期も, 低い時期もありました (図 5)。

ということは, $\mathrm{CO}_{2}$ 以外の要因があってもおかしくあり ません。その辺のメカニズムの解釈を採用したのがドイツ です。 2012 年には, すでに「シュピーゲル」がある本（Die 
Kalte Sonne: 冷たい太陽）の内容を紹介しています（図 6)。 内容をお話しすると, 太陽からは常に太陽風と太陽磁場 が地球に吹き付けています。地球をとりまく雲は, 遠い天 の川から降り注いでくる宇宙線が大気の中に入って, エア ロゾルという雲のもとを作り，雲が形成されやすくなりま す。この宇宙線の侵入が多いときには雲ができやすくなり ます。しかし，これを邪魔するのが太陽磁場や太陽風です。 これまでのデータから，太陽風と銀河系から来る宇宙線の バランスで雲量が決まるという傾向が出ています。今後は 極端な温度上昇はないという予想をしています（図 7)。

しかし，最近は，これが少し乱れてきているというデー 夕も国立極地研究所から報告されています。

雲量を左右するメカニズムを断定するのは難しいのです が, 傾向として, 雲が増えると地球は冷えてきます。雲が 少なくなると地球は温まってきます。 $\mathrm{CO}_{2}$ よりも, 水蒸気 の方が圧倒的に大気の温暖化に寄与するのはよく知られて います。地球の大気温度に影響を与えるのは, 雲量, すな わちこれに影響する太陽の活動度の方であろうというのが このメカニズムの基本的な考え方です。

IPCC（気候変動に関する政府間パネル）は虚偽のデー 夕を捏造して, 極端な地球温暖化を公表したため, スキャ ンダルになり，極端な温度上昇予想を取り消しました。

太陽活動と雲量・気温のメカニズムですが, 今, 太陽活 動は停滞していて，非常に弱まっています。まだまだ弱ま ります。太陽は，11 年周期で南極と北極が入れ替わりま すが，この数年間は，完全に入れ替わらない状態が続いて います。このような状況がかつて存在し, 地球が寒冷化し た時代がありました。2020 年ごろには地球寒冷化が予想 されるということで, 覚えている方もいるかもしれませ んが, 2012 年 4 月, 国立天文台, 理化学研究所, NASA, ESA（欧州宇宙機関）などがそろつて，地球寒冷化を警告 しています。

東京工業大学の丸山茂徳研究グループも, 地球の温度に 一番影響するのは, 地球を取り巻く雲とか水蒸気の量, 2 番目に影響するのが温暖化ガス，その他に，地球が太陽の 周りを公転するときの摇らぎの角度, 地球磁場，火山活動 などと指摘しています。

ですから, 「 $\mathrm{CO}_{2}$ だけを取り上げて, 温暖化, 温暖化」 と言うのは科学的に問題があります。私たちが生きている 太陽系あるいは銀河系には，もつと複雑なメカニズムで, 私たちがまだまだ理解しきれていないものがたくさんある という考え方のほうが正しいと私は思っています。

今年 5 月, 毎日新聞が, 地球自身の磁気も弱まっている と報道しています。太陽からの太陽風とか磁場をガードし ている地磁気自身が，今，加速度的に弱まっているという のです。地磁気が弱まると，オーロラがもつと低い緯度で 見られるとか, 楽しい現象はまだいいのですが, 重大な通 信障害や，地球寒冷化も予想されています。

ですから, 宇宙のスケールで見ると, 私たちが予想し得 ないことが起きる可能性もあるので, $\mathrm{CO}_{2}$ だけに目をとら われていると危険です。
石油技術協会の皆さんには, むしろ $\mathrm{CO}_{2}$ をどうやって 商品にしていくか, ぞうやって付加価值を付けていくかと いうところで頑張ってもらいたいと私は心から願ってい ます。

\section{ドイツの再生可能エネルギー}

私はドイツのマックス・プランク金属研究所に 6 年間勤 務して, 帰国後すぐに, 当時, まだ高かった太陽光パネル を買いました。小さな太陽光パネルが 1 枚十何万円もしま した。それを湘南校舎の屋上に置いて, 太陽光発電を利用 して, GE 社製の SPE（固体高分子電解質）の装置があっ たので, それで水を電気分解し, 発生した水素を水素吸蔵 合金に貯めるという運転を 10 年近くやりました。

これをエネルギー・資源学会などで発表したところ, 散々 批判されました。まず, 太陽光ネルギーの研究をやること 自体, 変換効率が低いのになぜやるのか, 太陽光エネルギー の将来などは見えないと。また，1980 年代は，まだ燃料 電池が実用化されていなかったので,「太陽エネルギーを 水素に変換して何のメリットがあるのか」と散々批判され ました。

今でも, 再生可能エネルギーは, このまま固定価格買い 取り制度をやっていると, あちこちにたくさん造り過ぎる という説もあります。また, 原子力発電を再稼働させるた めにも再生可能エネルギーは増やしたくないという雾囲気 が日本政府にはあります。

ドイツは，すでに去年の段階で $28.5 \%$ が再生可能エネル ギーに移行しています。

私は, 去年 11 月に南西ドイツのバーデン・ヴュルテン ベルク（BW）州政府を訪問するチャンスがありました。 ちょうど黒岩知事が行くときだったので, ご一緒しまし たが, 州政府のクレッチマン首相が丸 1 日お付き合いして くれました。BW 州はドイツの緑の党の方が初めて首相に なっている州です。有名な黒い森がある州です。ところが, 首相は厳しい顔をされて説明を始めました。

風力発電が豊富にあるのは北海の方だが, ドイツの工業 地帯は南ドイツ側にあるのです。メルセデス・ベンツの本 拠地がある BW 州がある南西ドイツのシュツットガルト と, その東隣でバイエルン州がある BMW の本拠地がある ミュンヘンです。これがドイツの黒字を支えている重要な 2 大州で, この地域が大量の電力を消費します。もう 1 つ, 北の方にノルトライン・ヴェストファーレン州があって, ここも工業地帯が伝統的にあります。

問題は, 北の方で発電した電力をどうやって南の方まで 持ってくるかです。直流発電送電というアイデアがあって も, その途中のドイツの人たちには,「電磁場の影響は体 に良くない」と言って反対する人が多く, そんなに簡単に は電力線を南の方まで引けません。首相は苦渋の顔をされ ていました。

そして，一番困っているのは，原発をやめると決断した が，放射性廃棄物を処理する場所がないことです。どこへ 持っていっても反対されて, 持っていく場所がありません。 


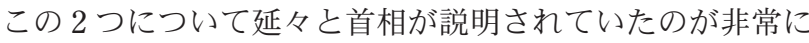
印象的でした。

ドイツは，政治の政策としていったん決めたら，頑固に 実行するのみですが，私たちが参考にできることがかなり あると思います。

ドイツは, 脱原発で再生可能エネルギーを導入したから, 電気代が上がって困るという話がよくあります。私の息子 家族はドイツで 10 年近く，年金暮らしの 90 歳を超えた義 理の母もドイツで生活していますが，家庭に大きな負担に なるほど電気料金は上がっていません。日本ではドイツの 再生可能エネルギ一導入について，ネガティヴに誇張され た意見があるようです。

ドイツの各地域には小さな電力会社がたくさんあり, インターネットで，「あなたの住んでいる地域には 10 社ぐ らいありますよ」と確認できます。新聞の購読と同じで,「1 か月契約してくれたら OK です」ということで，各社が電 気料金表を全部公表しています。1力月の接続料で，消費 者はその中から選択すればいいのです。さらにその会社と 接続契約をすると，「あなたは，100\%再生可能エネルギー の電気がいいですか。まだ少し残っている原子力や化石燃 料の発電が混じってもいいですか」という選択もできます。

そして，非常におせつかいなのですが，その家庭の 1 年 間の電気の使い方が，いいとか悪いといった報告書までつ けてきます。こういうところが非常にうまく進んでいて， 小さな発電企業と住民とが一体になっているという気がし ます。

\section{日本の再生可能エネルギー}

日本の再生可能エネルギーをみると，太陽光発電を中心 に発電容量は伸びています。北海道, 本州, 四国, 九州の 各地域間の接続がもつとスムーズにいけば，電力量だけ考 えれば，例えば，北海道に集中して再生可能エネルギー施 設を置いて，それを全国に送電してもいいぐらいです。し かし, 分散型で使うのが本来の再生可能エネルギーの特徵 です。

では，あちこちに造つた場合，それをどうやって皆さん が効率よくうまく使えるようになるのか。今，各地で，電 力の発電・送電分離会社ができてきている最中だと思いま す。しばらくは混乱するでしょうが，これからが消費者に はメリットが出てくる面白い時期になるだろうと思います。

神奈川県の例では，伝統的に誇れる再生可能エネルギー はが丹沢山塊にあるダムの水力発電です。全国の自治体の 中で水力発電容量が一番大きいのは神奈川県です。そして 太陽光発電容量も増えてきましたし，バイオも含めると, 神奈川県の再生可能エネルギー発電容量は 1.2 ギガワット を超えました。原発 1 基分を軽く超える再生可能エネル ギー発電容量です（図 8)。

日本の再生可能エネルギーの設備容量では，現在，約 28 ギガワット以上あると言われています。これも時間の 関数でどんどん変わっているわけですが，これからさらに ぞのぐらい伸びるのか，あるいはどこで止まってしまうの
か，これからの日本のエネルギー政策との絡み合いだと思 います。

次に, 京浜臨海工業地帯を少し紹介させてください。川 崎市と横浜市にまたがっているこの地域の火力発電容量は 6.3 ギガワットです。計画中のものまで全部入れると 8 ギ ガワットです。あの小さな地域に, 何と原発 8 基分の電力 源があるのです。

「神奈川県は, 目を覚ましてエネルギーで商売をやるべ き」と話しています。しかし，こんな巨大なエネルギー源 が首都圏の近くにあることも事実です。

$$
\text { 水素エネルギーとは }
$$

水素エネルギー利用は, 1960 年代頃からアメリカを中 心に伸びて, その後, 世界に広がりました。しかし, 世界 が目を向けるようになったのは，やはり燃料電池技術が商 品として出てくるようになってからです。ようやく「水素 は使える」というように見てもらえるようになりました。

エネルギーは， 1 次エネルギーと 2 次エネルギーに分類 されます。水素エネルギーは, 1 次エネルギーを使って造 り出す 2 次エネルギーです。

なぜクリーンと言うのか。炭素原子と水素原子から構成 される化石燃料を $\mathrm{C}_{m} \mathrm{H}_{n}$ の形で表せば, $\mathrm{C}(m=0) \mathrm{H}(n=2)$ が水素です。酸素と燃焼しても $\mathrm{CO}_{2}$ を出さないからクリー ンと言われています。

水素には使い方が 2 つります。水素を消費して使う方 法, と水素を消費しないで繰り返して利用する方法です。 (図 9)

<水素を消費する方法 > 水素と酸素を化合させて水にす るときに電気が出ますね。ちょうど電気分解の反対の使い 方です。燃焼反応（ロケットエンジンなどの内燃機関燃料 として）と電気を発生させる反応（燃料電池）を利用する ものです。

く水素を消費しない方法 > 水素吸蔵合金にためた水素を 放出させて,もう 1 つの水素を貯蔵していない合金に送り， この 2 つの合金間で水素の吸収・放出反応というキャッチ ボールをするときに発生する合金の熱反応を利用する方法 です。この場合, 水素を吸収するときには発熱反応, 水素 を放出するときには吸熱反応が生じます。この熱反応は, 冷える現象を利用することで冷凍機・冷水製造もできます。

水素を消費しない技術は，二ッケル水素蓄電池という充 電池にも利用されています。ここでは水分子から解離した 水素イオンが電池の負極である水素吸蔵合金に入り（充 電), あるいは合金から出て (放電), 繰り返して電池が利 用できます。エネループはまさにそうです。トヨタのプリ ウスに使われている充電池も同様です。

\section{水素の性質}

水を電気分解し, 発生した水素と, 空気中の酸素を反応 させて，このときに発生する電気でモーターを回すという のが基本的な燃料電池の原理です。電気分解の逆というこ とで, 皆さん, 中学校で勉強した水の電気分解を思い出し 
てください。

試験管を逆さまにして水の中に入れて, 水素ガスと酸素 ガスを集めましたね。溜まつた水素の試験管の方に，マッ チで火をつけると,「ピュ」という音で引火すれば成功です。 もたもたしていると, 空気中の酸素が多めに水素ガスに混 じって，引火し，試験管が割れたりしたこともあるかもし れません。「水素は爆発する,危ない」と言われる原因です。

よくドイツのヒンデンブルク号の爆発事件が出てきます ね。あれは水素が爆発原因ではありません。飛行船の機体 の布には，酸化鉄とアルミの混合物のテルミットと言われ る材料が塗装してあり，そこが空中で帯電し，放電した火 花がまず布に燃え移り，それから内部の水素ガスへ引火し たと言われています。だから，中がへリウムガスだったと しても, 機体の布は然える可能性があったということです。 また，水素ガスへの引火で然えたために，発熱量が比較的 小さく, 3 分の 2 以上の人が助かっているのも事実です。

水素は, 拡散速度がすごく速く, 私は長年, 水素ガスを 使つた実験をやってきましたが，水素が少し漏れても，1 秒もたたないうちに 5 メートル以上離れた天井の水素検知 器警報機が鳴ります。猛烈に速く拡散しますから，空を開 けておくとか，排気さえしつかりして，水素ガスをためな いようにすることで，水素ガスは安全に使えます。どんな 燃料も，ためて，引火すれば危険です。

1970 年以前, 都市ガスで自殺する人がいました。何で 都市ガスで自殺できるのかと思ったら, 当時は $\mathrm{CO}$ と $\mathrm{H}_{2} \mathrm{O}$ の混合ガスでした。今では，都市ガスはメタンが主なガス で, CO は含んでいません。

ですから，実は，私たちは伝統的に水素をかなり燃やし て使ってきたという実績もあります。

\section{燃料電池の動作原理}

燃料電池には, 定置用と動力用の使い方があります。定 置用はエネファーム，動力用は燃料電池自動車ということ で，これからとても大きな市場展開が期待されています。 5 兆円以上というと, 従来の原発市場，あるいは放射線を 利用した医療・工業の市場とほぼ同じぐらいになります。

燃料電池を動作させるためには，水素ガス分子と酸素ガ ス分子を，それぞれ解離させて原子状にする必要がありま す。シンプルですが，水素分子と酸素分子は，どちらも共 有結合分子ですから, この共有結合をどうやって切り離し て，お互いに原子状にして化合させるか。ここが重要なポ イントです。

共有結合を切るためには, 電子が必要です。高温度であ れば，共有結合分子は電子を金属側からもらって原子に解 離できますが，通常，金属表面は酸化膜で被われていて， 電子を出すことができません。 $100^{\circ} \mathrm{C}$ 以下の低い温度では, 金属酸化被膜は安定です。そこで, 低温でも共有結合を解 離させることができる金属というと, 白金しかありません。 この高価な白金の使用量を減らしても，燃料電池が効率良 く動作するような研究開発が長年にわたり行われてきまし た。最近, 燃料電池のコストが下がつたのも, 白金使用量
を大幅に減らすことができた結果です。

\section{燃料電池の利用例}

電気として 45\%, 熱として $42 \%$, トータル $87 \%$ で使え るのが定置用燃料電池のエネファームです。改質器が優れ ているので, 天然ガス, 下水道, 廃棄物, メタンガスから でも水素を取り出して, 発電できます。

埼玉県庁にはホンダのソーラー水素ステーションがあり ます（図 10）。

太陽光で発電した電気で水を電気分解して，350気圧ま で昇圧できるので, 直接, 燃料電池自動車に直接チャージ できるシステムです。自動車の中に水素が十分にたまって いれば，逆に，インバーターを使って発電機にもなり，一 般家庭であれば 5 日から 1 週間ぐらいは十分に給電もでき ます。

トヨタは, 燃料電池バスには屋根に高圧水素タンクをた くさん積めるので, 体育館に避難した人たちに給電すると いう実験をしています。海外では,「日本はそんなものが 必要か」とよく言われますが, 「日本は, 毎年, 台風が来て, 体育館などに避難する人が出るので, これは非常に重要な んだ」という話をしています。

2013 年 4 月には, 最初の水素のステーションが神奈 川県海老名市のガソリンスタンドの中にできました（図 11)。当分の間, 燃料電池の車はめつたに来ませんから, 通常のガソリンステーションの中に水素ステーションを置 くことが大事です。

日本には各省庁の規制が多々あるために, 水素ステー ション 1 力所造るのに 5 億円ぐらいかかります。ヨーロッ パやアメリカの 5 倍もかかるのが現状です。今年の 1 月だつ たと思いますが，安倍晋三首相が自分で然料電池自動車を 運転しながら,「規制緩和をしなきゃいけませんね」と言つ ていました。まさにどんどん進めてもらいたい。

私も, 今, 神奈川県を中心に, 水素社会の実現に向けて 活動をしています。2019 年には東京で大きな水素国際技 術展－WHTC（世界水素技術会議）2019を開催する予定 です。舛添要一東京都知事が積極的で, 力を入れています ので, 東京都と神奈川県が一体化して, この会議を成功さ せたいと思っています。

\section{なぜ燃料電池自動車が注目されるのか}

天然ガスから水素に転換して, 燃料電池自動車に利用す ると, エネルギー利用効率が $40 \%$ 近いのに対して, 原油 精製からガソリン車へ利用するときの利用効率は $20 \%$ 程 度です。ざっと見て燃料電池自動車の方が, 2 倍もエネル ギー利用効率を高く使うことができるのです。世界中が然 料電池自動車に注目している大きな理由です。

もちろん, ハイブリッド車も決して悪くありません。天 然ガスもいいでしょう。ただ, これは, 化石燃料, 再生可 能エネルギーなどを, どのように利用して, 産業を回して いくのかという社会システムの問題になります。

水素ステーションでは, 3 分間で 700 気圧の水素ガスを 
満夕ンにできます。水素 1 キログラム 1,000 円ぐらいです から, 満タンで約 6,000 円の売り上げになります。一方, 電気自動車は, 30 分ぐらいかけた充電しても, 数百円取 れるかどうかです。喫茶店でコーヒー 1 杯で延々と粘る人 と同じようなものですから，燃料ステーションとしては困 ります（図 12）。

\section{再生可能エネルギーを水素として貯蔵する}

水素と再生可能エネルギーは非常に相性がいい関係で す。人が行けないような所に，例えば，無人の風車とか太 陽光発電施設があっても, 発生した電気で水を電気分解し て，水素にして貯蔵しておいて，必要なときに燃料電池に つないで電力源とすることが可能です。

再生可能エネルギーは，晴れたり量つたり，風が吹いた り吹かなかったり, 常に変動します。基本的に再生可能工 ネルギーは「ためて使う」のが根本です。意外とこの基本 が理解されていません（図 13）。

再生可能エネルギーのため方はいろいろあります。蓄電 池で化学的にためるのも 1 つです。水を電気分解して水素 にしてためるのも 1 つです。それ以外にもいろいろなため 方がありますが，今，比較的広がつているのは，蓄電池を 使つたため方ですね。私自身は, 水素吸蔵合金を利用して, 水素としてためる方法を勧めています。圧倒的に安全で, 長期間安定して貯蔵できるからです。

1980 年代からずっと実証してきたシステムがあります (図 14)。太陽光エネルギーと風力エネルギーの両方を, SPE (固体高分子電解質) 槽を使って水を電気分解します。 そして発生した水素を水素吸蔵合金にためておいて，必要 なときに燃料電池につなぐというシステムです。これを使 えば，水素は $20 〜 30$ 年ためておいても全く問題なく安定 して使えます。これはテスト済々です。水素吸蔵合金に水 素をためれば，高圧ガスタンクは要りません。10気圧以 下で水素吸蔵合金タンクに水素化物として安定に，長期間 ためることができます。

\section{水素吸蔵合金を利用した水素を消費しない技術}

水素吸蔵合金は，私たちが空気を吸うよりも速く水素を 吸収，放出できる金属材料です。水素は合金を構成する原 子の隙間に出入りします。同じ体積で比べると，合金は液 体水素よりもたくさんの水素を，より高密度でため込むこ とができます（図 15）。

この反応を利用しているのがニッケル水素電池です。 1988 年，私たちは充放電が 1,000 回以上できることを実証 しました（図 16）。これが，後に実用化されてプリウスに 搭載され，ハイブリッドカーが普及し，また小型の蓄電池 エネループという商品も出るようになりました。

電池への使い方以外に，合金の発熱・吸熱という可逆的 な熱反応の使い方があります。水素吸蔵合金は，水素を吸 収するときに発熱します（図 17）。次に，たまっている水 素を放出するときには，吸熱反応なので，周囲から熱を奪 うので，周りが冷えます（図 18）。
図 19 をみてください。まず, 水素をためている吸蔵合 金に，ごみ焼却場とか発電所から出てくる排熱，例えば $100^{\circ} \mathrm{C}$ 程度の水蒸気を当てます。そこで水素が放出されま すそして，もう 1 つの水素を吸収していない空の合金へ水 素を送ります。この合金が水素を吸うと発熱しますが，こ の発熱反応は使いません。地下水をこの合金タンクの周り に接触させておいて, 水素を放出させると, 吸熱反応によ り地下水が冷えていきます。この冷却する熱反応を繰り返 すことで, 地下水温度を $0^{\circ} \mathrm{C}$ 程度まで冷やすことができま す。工場排熱と水素吸蔵合金を使うだけで，容易に冷水が 製造できます。

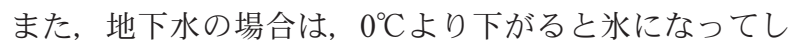
まうので, 氷点下まで冷凍する場合には, 炭化水素冷媒を 水の代わりに使います。この方法で, $60 \mathrm{~m}^{3}$ の空間を $2 つ$, $-30^{\circ} \mathrm{C}$ まで冷やした冷凍庫も実証しました。使うのは排熱 と水素吸蔵合金の反応熱だけです。

冷水製造や冷凍機の実証を, 愛媛県西条市でこの 10 年 以上にわたり，経済産業省や日本製鋼所（JSW）の協力で 実証してきました。

冷水は, $1,000 \mathrm{~m}^{3}$ のビニールハウスの中でイチゴ栽培に 利用しました（図 20）。ハウスの中が高温になっても，个 チゴは，植えられているプランターの中で冷水が流れてい る限り成長します。それを実証して,「水素イチゴ」とい う商標も登録しました。この水素イチゴは経済産業省のプ ロジェクト成果だったので, 販売はできず, 地元の方々に 嫌というほどたくさん食べてもらいました。

一方, $0^{\circ} \mathrm{C}$ か $5{ }^{\circ} \mathrm{C}$ の冷水は, 陸上養殖にも利用できま す（図 21）。地元のサツキマスの養殖に適用しました。東 海大学海洋学部秋山信彦教授の協力を得て, 養殖からふ化 まで全部成功しました。川魚は，塩水を浴びると，体が塩 分の刺激を受けて，口が曲がり，マスにだんだん変わって いきます。肉も，川魚の白色からピンク色に変わります。 そうすると，付加価值がぐんぐん上がります（図 22)。

水素イチゴやサツキマスの陸上養殖の実証から, 西条産 業情報センターを通して，特許を 6 件公開しました。

排熱と水素吸蔵合金の反応熱だけを使う冷水製造では, 通常の電気式チラーを利用した場合に比べて，80\%以上の 省エネ効果, $\mathrm{CO}_{2}$ 削減効果があることも実証しました。

本当は，この世界初の実証をさらに発展させたかったの ですが, 残念ながら, 昨年, 西条市長が代わった途端にす べて実証施設は閉鎖，廃棄になってしまいました。

しかし, 排熱があふれている京浜工業地帯やその他の地 域でこの技術は使えます。ご興味ある方はご連絡下さい。

\section{水素が地方の産業と経済を活性化一地方創生に貢献}

愛媛県西条市でなぜこのような実証をやるようになつた のでしょうか。2000 年ごろに当時の伊藤宏太郎前西条市 長とお会いました。伊藤前市長が，「大企業を招致して大 きなコンビナートを造つたが，すべて撤退してしまった。 税収もない。雇用もない。どうしたらいいものか」と言う ご相談がありました。

J. Japanese Assoc. Petrol. Technol. Vol. 80, No. 4 (2015) 
「ここには美味しいうちぬきという地下水が豊富にある のだから，水素冷凍技術で，ここに大食料倉庫を造りませ んか」と提案しました。すかさず市長は,「分かつた。じゃ あ, ここで地元産の野菜を加工，貯蔵して，これを関西に 出そう」という食料コンビナート構想ができ上がりました。

このようにして 10 年以上にわたり西条市の農業, 産業 育成にご協力してきましたが，2014 年には，経団連から 未来都市モデルプロジェクト実証地域，農林水産省からは 西条農業革新都市総合特区の指定を受けて, 全く新しい動 きに発展しています。

水素がきっかけで, 農業関係の活動が活発になったのは 非常にうれしいことです。特に食品関係は, とても大事な ものです。

\section{おわりに}

雑多なお話をしましたが，日本のエネルギー政策は大き な分岐点にあると思います。再生可能エネルギーや水素エ
ネルギーが普及するまでは, クリーン火力を積極的に利用 すべきです。そして $\mathrm{CO}_{2}$ を新たな炭素源として，新材料 や新商品の開発を行ってください。また, 海外に日本のク リーン火力発電技術を輸出すべきです。

勤務先の大学では定年を迎えましたので, 研究生活から 抜けながら, 現在は, 川崎市の溝の口にあるかながわサイ エンスパーク (KSP) の経営, 管理に精力を注いでいます。 全国の大学発ベンチャー支援プロモータ, ベンチャー起業 投資事業, 起業家育成教育などを行っています。KSP に は約 120 社の研究開発企業が入居しています。70 社が大 手企業, 50 社がベンチャー企業です。 5,300 人ほどの人た ちが日々活躍しています。ホテル, レストラン, コンビニ, 銀行, 郵便局, 医療クリニクなどを備える小さな夕ウンで, 地元地域との交流も盛んです。溝の口の駅からは無料シャ トルバスを運行していますので, ぜひ一度お出掛けくだ さい。

ご清聴どうもありがとうございました。 


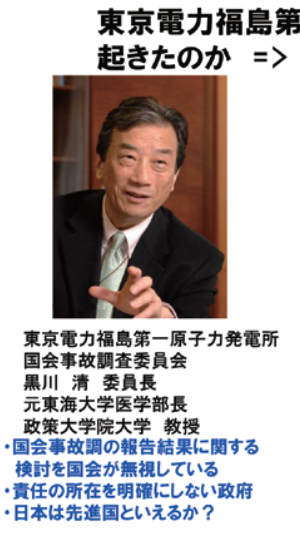

一原子力発電所では何が

のまま再稼働へ

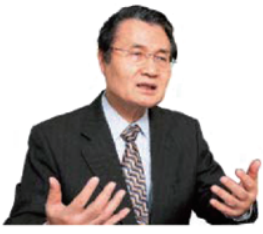

福島原発事故独立掺就委員会 (民間事故調查委員会) 故 北瀑 宏一委員量

・原烟は人䫐・社会にリスクが大ぎ すきる

・原発事故が引き起こした環境破壤 は容易に修復できない

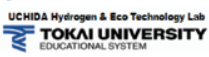

図 1

原子力工学＝原幾ではない

-「原子カ＝原子の力」を利用する技術

- 不安定な原子搆造からより安定した原子搆造に変 化しようとする際に、粒子または電磁波の形で放出 されるのが放射線

1) 電磁放射線 線 ガンマ䋥

2）粒子放射線 アルファ線 ヘー多線 中性子線 <利用技術>

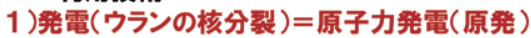
核兵器(高濃縮ウラン)

2 )医療・農業・工業・産業に利用

3)宇宙開発における放射線防御

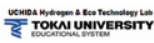

図 2

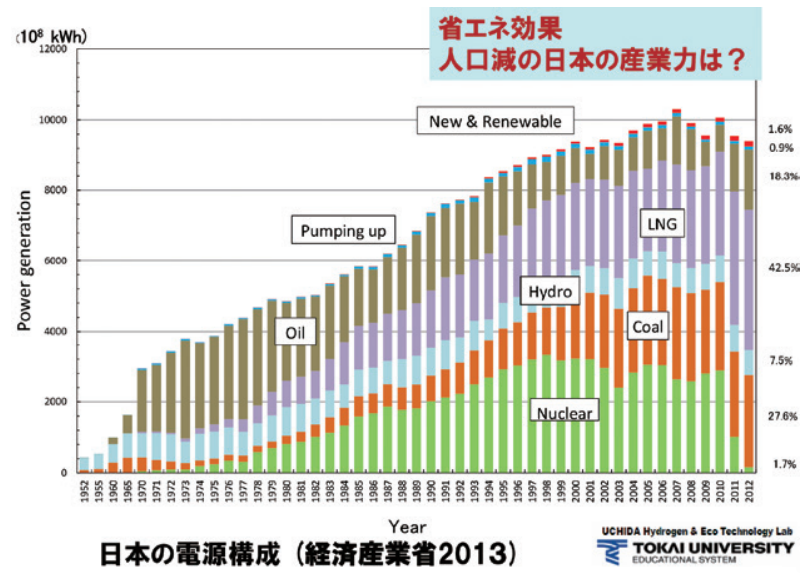

図 3

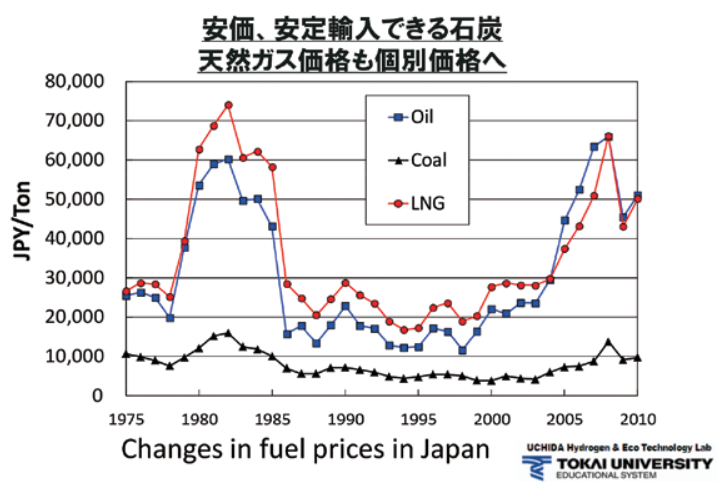

図 4

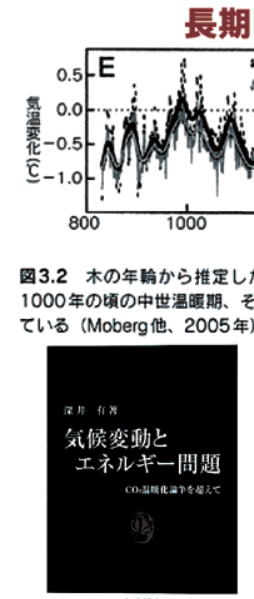

中舟的为
長期間で気温変化をみれば No Corr. ( $\cong E C S$ )

1 RUNNINGr + Normalization + LS Corr. (ECSva) Nivendy Num $1200 \quad 1400$ $1600 / \frac{1}{1800} 200$

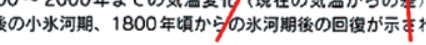

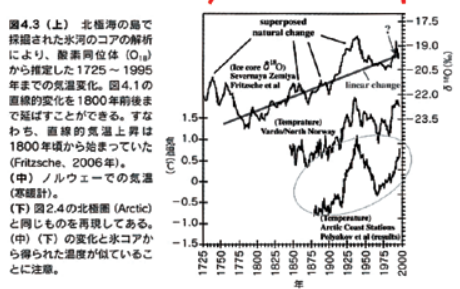

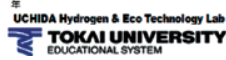

図 5

宇宙線、太陽磁場、雲量の関係

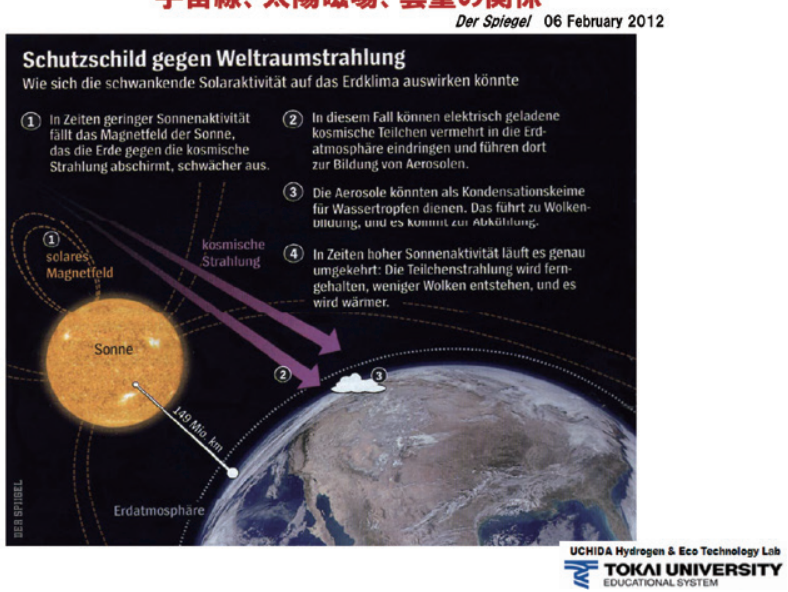

図 6

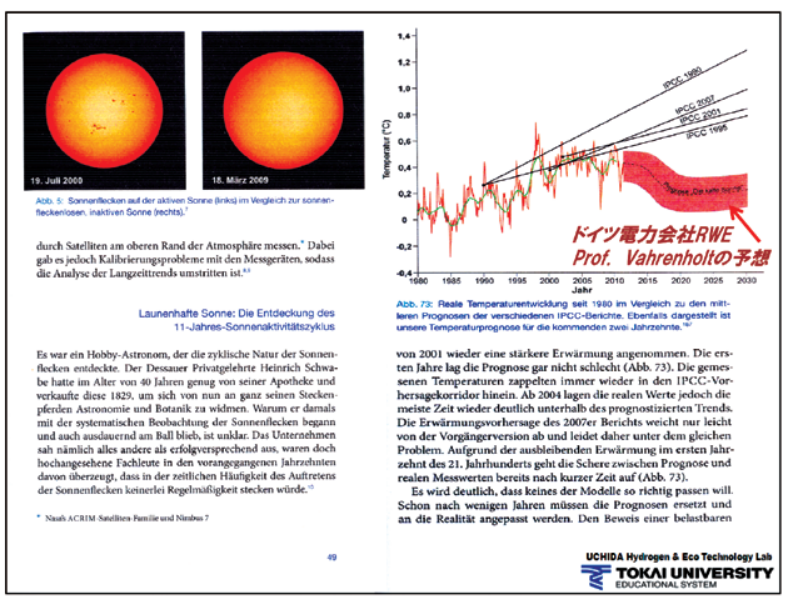

図 7 
神奈川県: 水力発電設備容量が国内最大

再生可能エネルギー発電容量 $=1.2 \mathrm{GW}$ 超

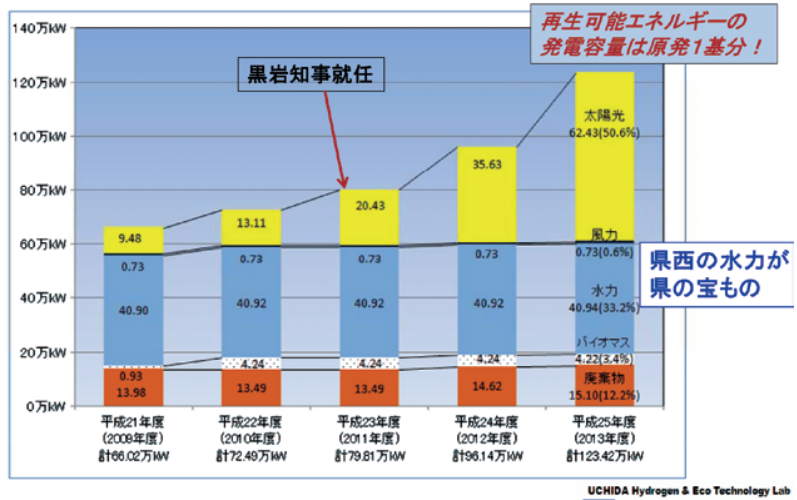

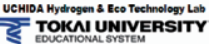

図 8

\section{2つの使い方}

1. 水素を消費する使い方〈創エネ> $>$ 燃料電池(FC) エネファーム・燃料電池自動車 >ロケットエンジン など

2. 水素を消費しない使い方

水素を繰り返し利用するく省エネ・畜エネ> $>$ 水素吸蔵合金を利用

$>$ 排熱、電気、不安定な再生可能エネルキー眝䓛

>水素吸葴合金十排熱利用を組み合わせると

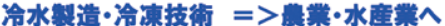

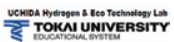

図 9

HONDA太陽・水素ステーション 燃料電池自動車は発電機にもなる!
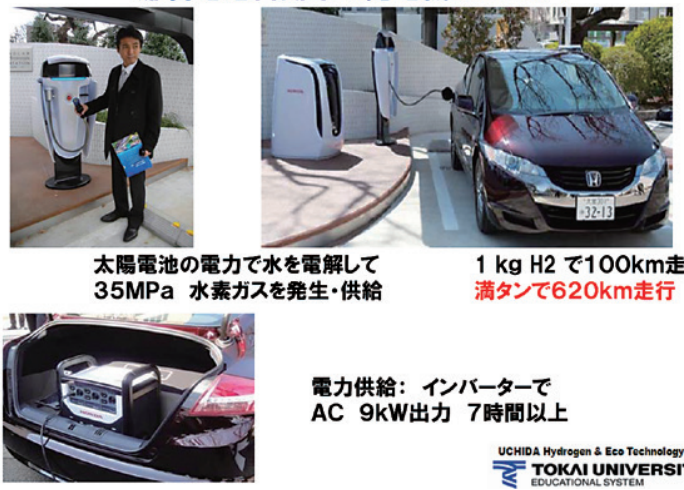

1 kg H2 で100km走行 满タンで620km走行

電力供給：インハーターで

AC 9kW出力 7時間以上

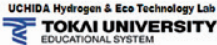

図 10

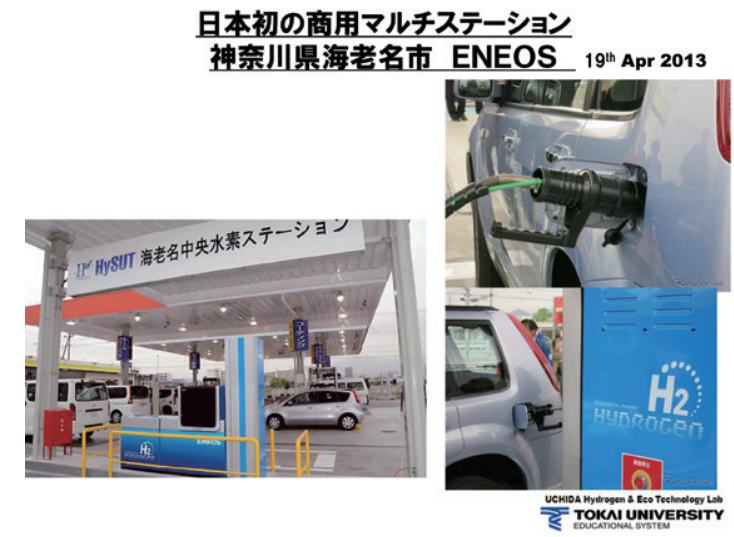

図 11

\section{然料電池自動車と電気自動車 燃料供給時間と売値}

電機自動車: $30 \mathrm{~min}$ で数百円

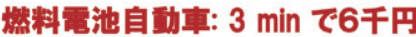

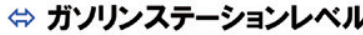
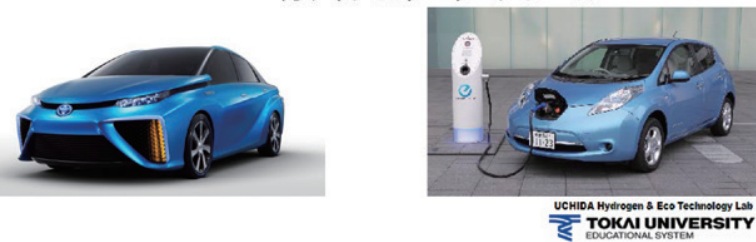

図 12

電気と水素で再生可能エネルギー眝蔵

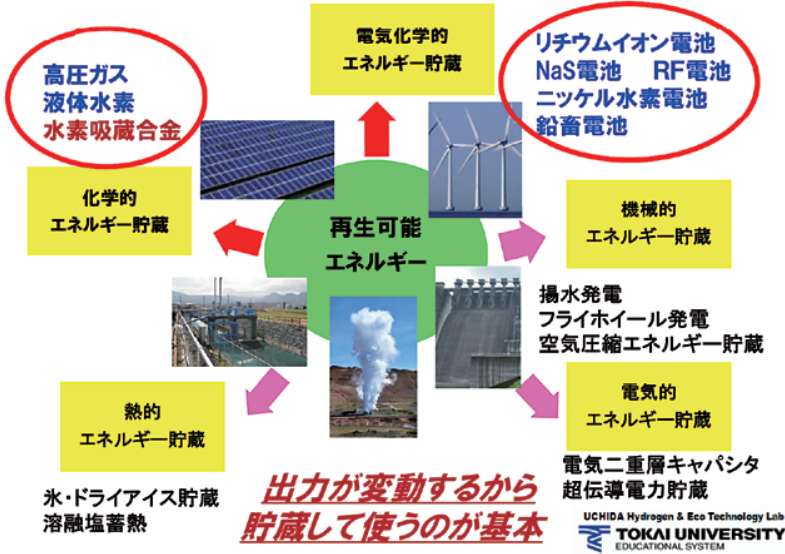

図 13

風カ・太陽エネルギーを水素として 眝蔵するシステム( 80 年代から実証中)

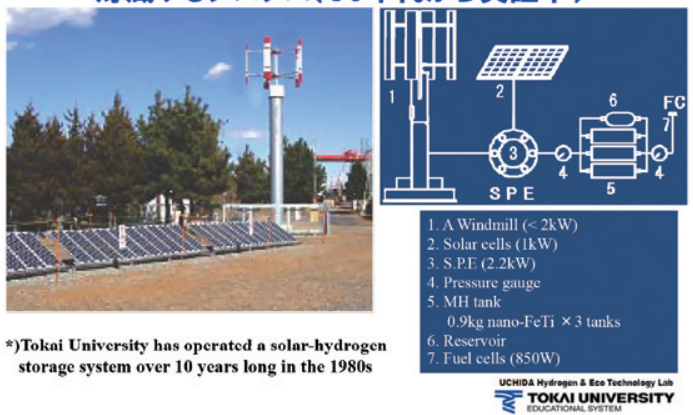

図 14

ナノ化水素吸蔵合金による水素眝蔵 反応が速く安いFeTi合金

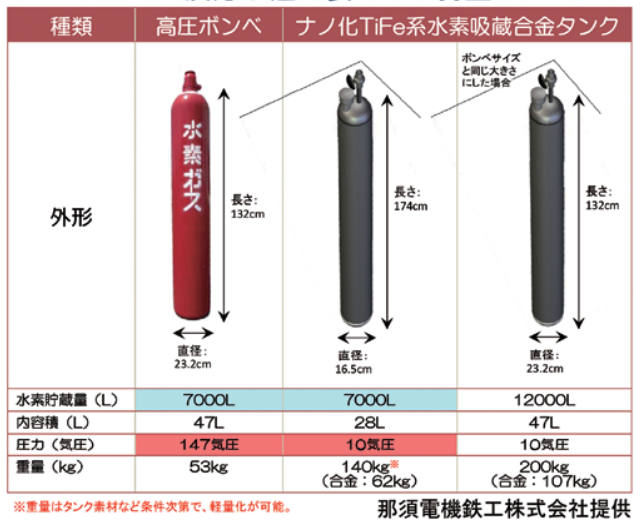

図 15 


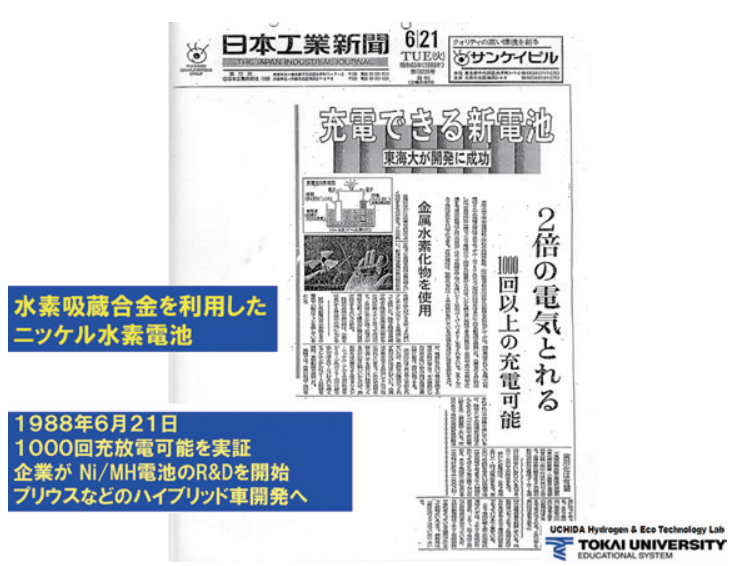

図 16

水素吸蔵合金が水素を吸収すると On $\mathrm{H}_{2}$ absorption (uptake)

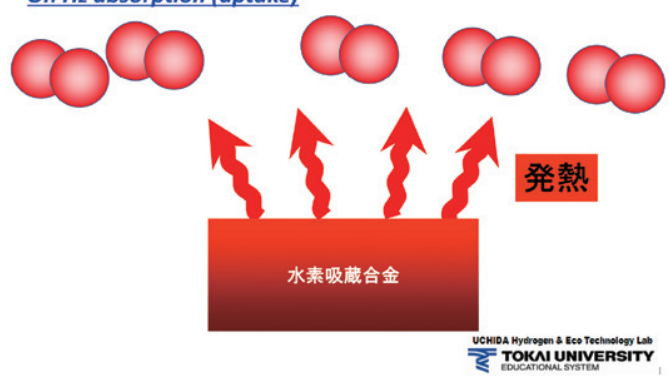

図 17

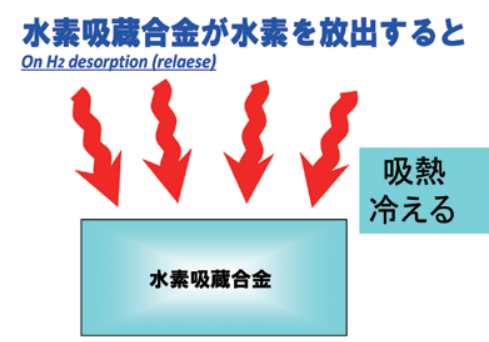

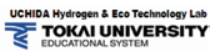

図 18

\section{水素と排熱を利用した冷水製造·冷凍システム}

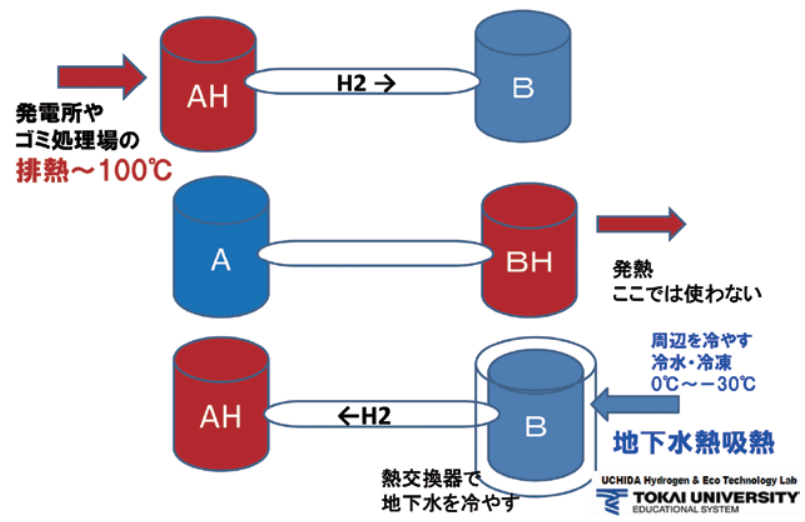

図 19

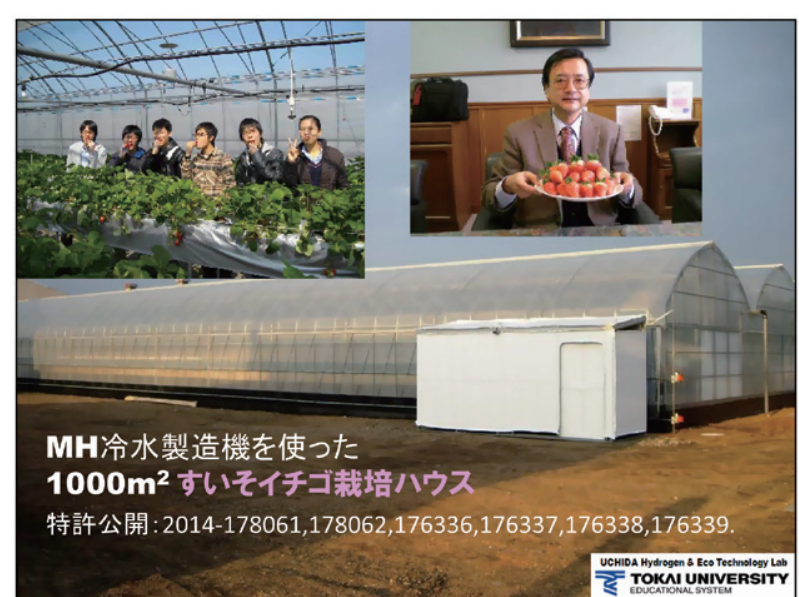

図 20

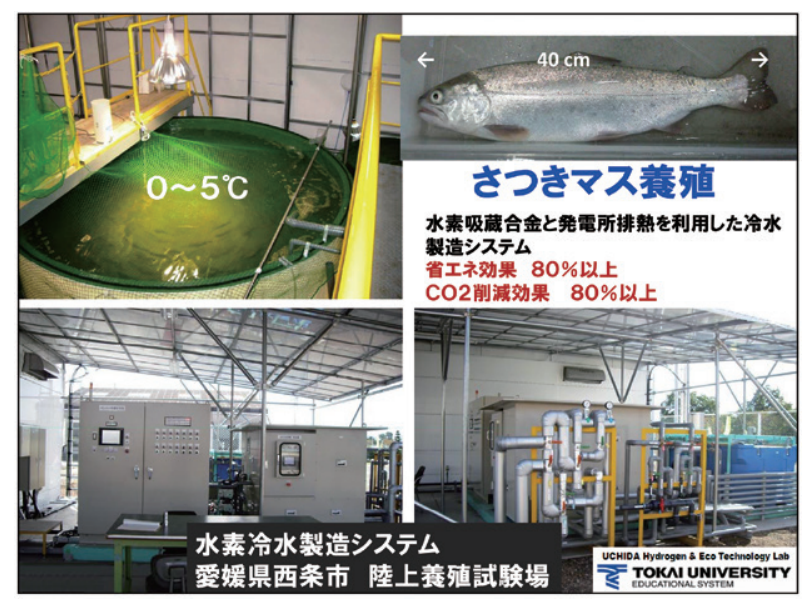

図 21

サツキマスの孵化、養殖、変態

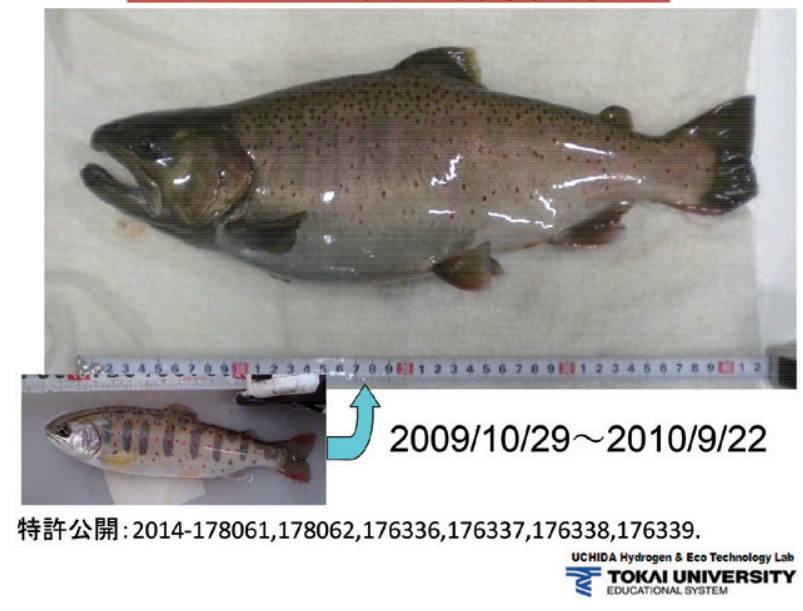

図 22 